\title{
Air and seawater pollution and air-sea gas exchange of persistent toxic substances in the Aegean Sea: spatial trends of PAHs, PCBs, OCPs and PBDEs
}

\author{
Gerhard Lammel $^{1,2}$ • Ondřej Audy ${ }^{1}$ - Athanasios Besis ${ }^{3} \cdot$ Christos Efstathiou $^{1}$ • \\ Kostas Eleftheriadis ${ }^{4}$ - Jiři Kohoutek ${ }^{1}$ - Petr Kukučka ${ }^{1}$ - Marie D. Mulder ${ }^{1}$. \\ Petra Přibylová $^{1}$ - Roman Prokeš ${ }^{1}$ - Tatsiana P. Rusina ${ }^{1} \cdot$ Constantini Samara $^{3}$. \\ Aysun Sofuoglu ${ }^{5} \cdot$ Sait C. Sofuoglu $^{5}$ • Yücel Taşdemir ${ }^{6} \cdot$ Vassiliki Vassilatou $^{4}$. \\ Dimitra Voutsa $^{3} \cdot$ Branislav Vrana $^{1}$
}

Received: 19 November 2014 / Accepted: 11 March 2015 /Published online: 25 March 2015

(C) Springer-Verlag Berlin Heidelberg 2015

\begin{abstract}
Near-ground air (26 substances) and surface seawater (55 substances) concentrations of persistent toxic substances (PTS) were determined in July 2012 in a coordinated and coherent way around the Aegean Sea based on passive air (10 sites in 5 areas) and water (4 sites in 2 areas) sampling. The direction of air-sea exchange was determined for 18 PTS. Identical samplers were deployed at all sites and were analysed at one laboratory. hexachlorobenzene (HCB), hexachlorocyclohexanes (HCHs) as well as dichlorodiphenyltrichloroethane (DDT) and its degradation products are evenly distributed in the air of the whole region. Air concentrations of $p, p^{\prime}$-dichlorodiphenyldichloroethylene ( $p, p^{\prime}$-DDE) and $o, p^{\prime}$ -
\end{abstract}

Responsible editor: Philippe Garrigues

Electronic supplementary material The online version of this article (doi:10.1007/s11356-015-4363-4) contains supplementary material, which is available to authorized users.

Gerhard Lammel

lammel@recetox.muni.cz

1 Research Centre for Toxic Compounds in the Environment, Masaryk University, Brno, Czech Republic

2 Multiphase Chemistry Department, Max Planck Institute for Chemistry, Mainz, Germany

3 Department of Chemistry, Environmental Pollution Control Laboratory, Aristotle University, Thessaloniki, Greece

4 Institute of Nuclear Technology and Radiation Protection, NCSR Demokritos Institute, Athens, Greece

5 Department of Chemical Engineering, Izmir Institute of Technology, Urla, Izmir, Turkey

6 Environmental Engineering Department, Uludağ University, Nilüfer, Bursa, Turkey
DDT and seawater concentrations of $p, p^{\prime}-\mathrm{DDE}$ and $p, p^{\prime}-$ DDD were elevated in Thermaikos Gulf, northwestern Aegean Sea. The polychlorinated biphenyl (PCB) congener pattern in air is identical throughout the region, while polybrominated diphenylether (PBDE)patterns are obviously dissimilar between Greece and Turkey. Various pollutants, polycyclic aromatic hydrocarbons (PAHs), PCBs, DDE, and penta- and hexachlorobenzene are found close to phase equilibrium or net-volatilisational (upward flux), similarly at a remote site (on Crete) and in the more polluted Thermaikos Gulf. The results suggest that effective passive air sampling volumes may not be representative across sites when PAHs significantly partitioning to the particulate phase are included.

Keywords Air-sea gas exchange $\cdot$ Deposition · Passive sampling $\cdot$ Volatilisation $\cdot$ Fugacity ratios $\cdot$ Aegean Sea

\section{Introduction}

Persistent toxic substances (PTS) pose a hazard for ecosystems and human health as they undergo long-range atmospheric transport (LRT), are ubiquitous in the global environment and, through bioaccumulation along food chains, may reach harmful levels even in remote areas (UNEP 2003; WHO 2003). PTS include organochlorine pesticides (OCPs), such as hexachlorobenzene (HCB), hexachlorocyclohexane $(\mathrm{HCH})$, and dichlorodiphenyltrichloroethane (DDT), and banned industrial chemicals such as polychlorinated biphenyls (PCBs), banned in Europe since the 1970s, only recently restricted industrial chemicals, such as polybrominated diphenylethers (PBDEs), and combustion by-products, such as polycyclic 
aromatic hydrocarbons (PAHs, all combustion types) and also HCB (waste burning), which primary emissions are ongoing. LRT of chlorinated PTS (Semeena et al. 2006; UNECE 2010) and also of PAHs (Lammel et al. 2009; Galarneau et al. 2014) is enhanced by re-volatilisation from surfaces (multihopping; significance of secondary sources in air). The same can be expected for most other PTS, as they resist to degradation in the soil and surface water and are semivolatile (vapour pressures between $10^{-6}$ and $10^{-2} \mathrm{~Pa}$ at $298 \mathrm{~K}$ ). Environmental fate monitoring is needed for global PTS assessment (Klánová et al. 2011) and part of the National Implementation Plans of parties to the Stockholm Convention (UNEP 2014), including Greece and Turkey. High PTS levels in air and seawater are a concern in the Mediterranean environment (Lipiatou and Saliot 1991; Kouimtzis et al. 2002; UNEP 2002; Terzi and Samara 2004; Biterna and Voutsa 2005; Mandalakis et al. 2005; Tsapakis et al. 2006; Chrysikou et al. 2008; Chrysikou and Samara 2009). The Mediterranean region is characterised by strong urban and industrial sources and adjacent source regions (western, central and eastern Europe). Exposure to long-range transported pollution from central and eastern Europe is highest in summer (Lelieveld et al. 2002).

Passive air sampling (PAS) is most useful for PTS monitoring and mapping, although the uncertainty of concentration measurements is within a factor of 2-3 (Harner et al. 2006; Klánová et al. 2008). Trace contaminants in water can be quantified using hydrophobic passive water samplers (PWS) with an uncertainty of about a factor of 2 (Lohmann et al. 2012).

PTS concentrations were measured in air and water, and the direction of air-sea exchange were addressed in summer (July) 2012 in a coordinated and coherent way at sites around the Aegean Sea using passive air and water sampling techniques. Our knowledge of exposure of the marine environment towards PTS in this region is deficient, and the region as a whole had not been addressed before in a coherent sampling campaign. The aim of the study was to contribute to the characterisation of regional environmental exposure to PTS and identify possible sources, notably by identification of the direction of air-sea exchange. Identical samplers were deployed at all sites, and the samples were prepared and analysed at one laboratory.

\section{Methodology}

\section{Sites}

Eleven sites in five areas around the Aegean Sea were selected to cover the major conurbations (urban and residential sites), coastal countryside and islands (rural and remote sites) (Fig. 1). Air was sampled at two remote sites at the coast of Crete island, in southern Greece, at seven rural/residential sites in central and northern Greece and in western Turkey, as well as at one urban site in Thessaloniki, northern Greece. Surface seawater was sampled at one of the Cretan sites and at three sites in the Thermaikos Gulf, northern Aegean Sea (Table 1).

\section{Sampling}

Air

PTS were collected by PAS using polyurethane foam (PUF) disks (Molitan, Gumotex, Czech Republic; density of $0.030 \mathrm{~g} \mathrm{~cm}^{-3}, 150 \mathrm{~mm}$ diameter, $15 \mathrm{~mm}$ thickness): Before use, PUF disks were cleaned through 8-h Soxhlet extraction with acetone and dichloromethane (DCM) and placed in a glass cartridges. PUF disks were deployed in protective chambers consisting of two stainless steel bowls (upper $30 \mathrm{~cm}$ diameter and lower $24 \mathrm{~cm}$ diameter; Klánová et al. 2008).

PAS were deployed during 28-30 days at each site (see Table 1), except at Selles Beach (11 days, 2-13 July 2012) and at Nilüfer-Bursa (42 days, 2 July-13 August 2012). All PAS data are corrected for field blanks. Between one and four field blanks were produced at each sites by leaving the PUF disks exposed within the PAS for a few seconds and keeping all other operations identical to sample processing. Values below the mean of the field blank values, $b$, plus three relative standard deviations $(\sigma)$ of the field blank values were considered $<\mathrm{LOQ}(\mathrm{LOQ}=b+3 \sigma)$.

The effective sampling volume of PAS, $V\left(\mathrm{~m}^{3}\right)$, needed to convert measured contaminant mass (pg) into atmospheric concentration $\left(\mathrm{pg} \mathrm{m}^{-3}\right)$, is dependent on substance properties ( $K_{\text {oa }}$; Shoeib and Harner 2002), gas-particle partitioning (very low sampling efficiency for particles), temperature and wind speed (Klánová et al. 2008). For our study, it cannot be derived from previous side-by-side active air sampling (AAS) and PAS (such as Bohlin et al. 2014), since no such data exist for the Mediterranean climate. Therefore, we experimentally estimated V carrying out side-by-side AAS and PAS during the campaign, at site 1a, Finokalia. This procedure is detailed in the Supplementary Material (SM), S2.

\section{Water}

Altesil silicone rubber (SR) sheets (Altec, Great Britain) were deployed simultaneously to the PAS for sampling of free dissolved contaminants in water. The sampling method is based on diffusion and absorption of hydrophobic contaminants from water to the silicone rubber polymer (Rusina et al. $2007,2010)$. Each sampler consisted of six sheets $(55 \times 90 \times$ $0.5 \mathrm{~mm}$ ). Briefly, before exposure SR sheets were cleaned with ethyl acetate $(24 \mathrm{~h})$ in a Soxhlet extractor, and spiked with a mix of 14 performance reference compounds (PRCs; D10-biphenyl and 13 PCB congeners not occurring in the 
a)

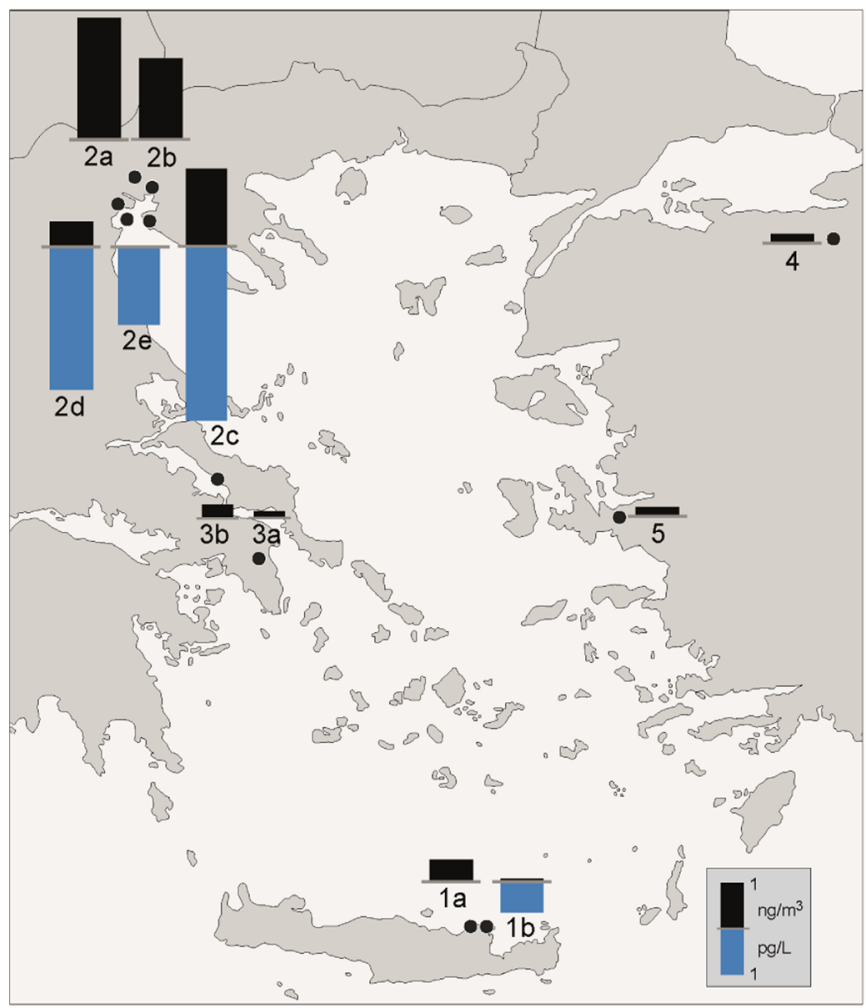

c)

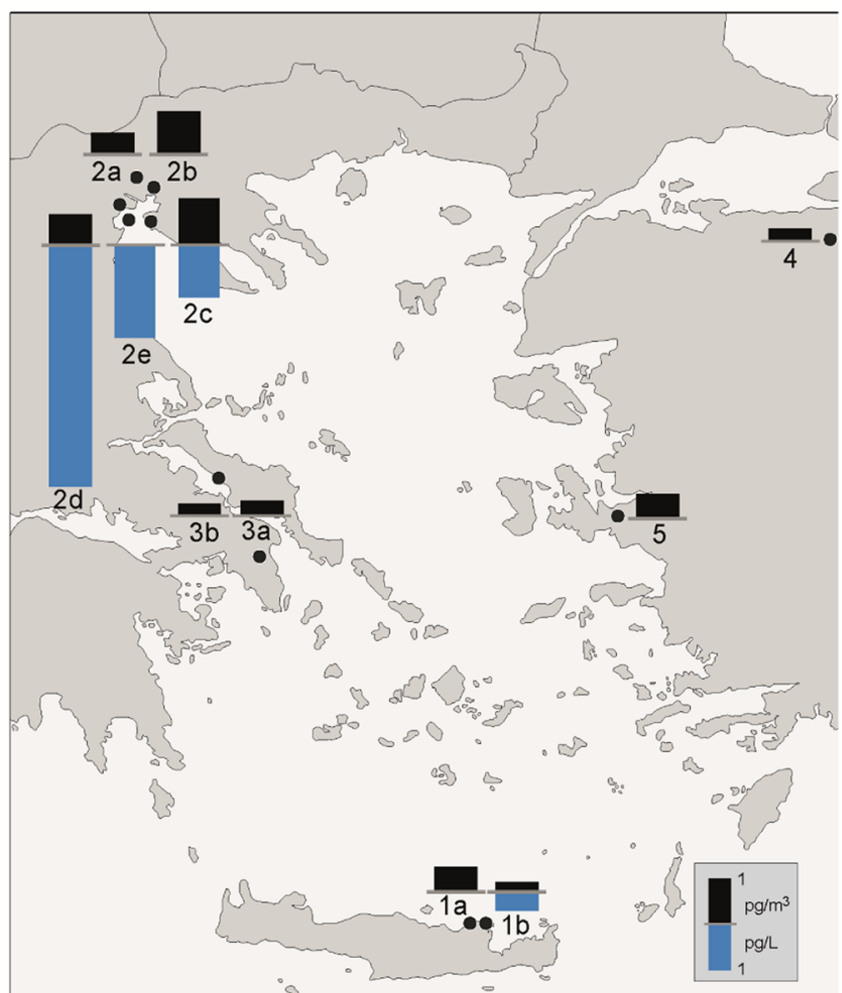

b)

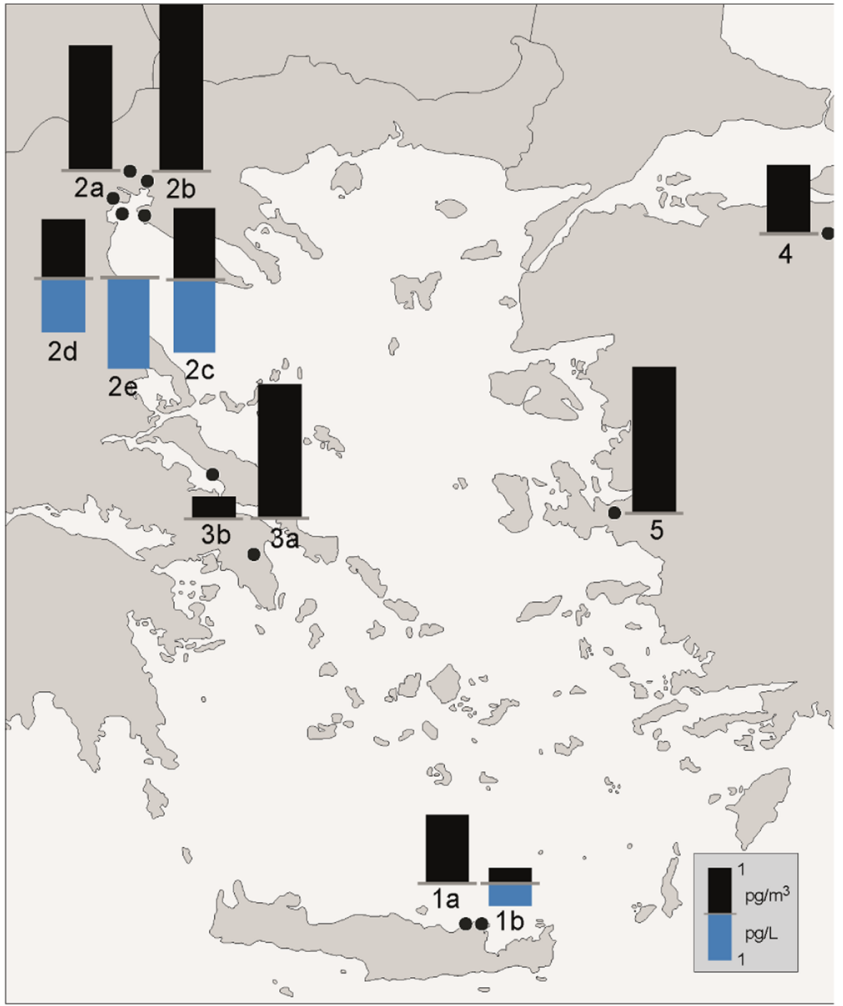

d)

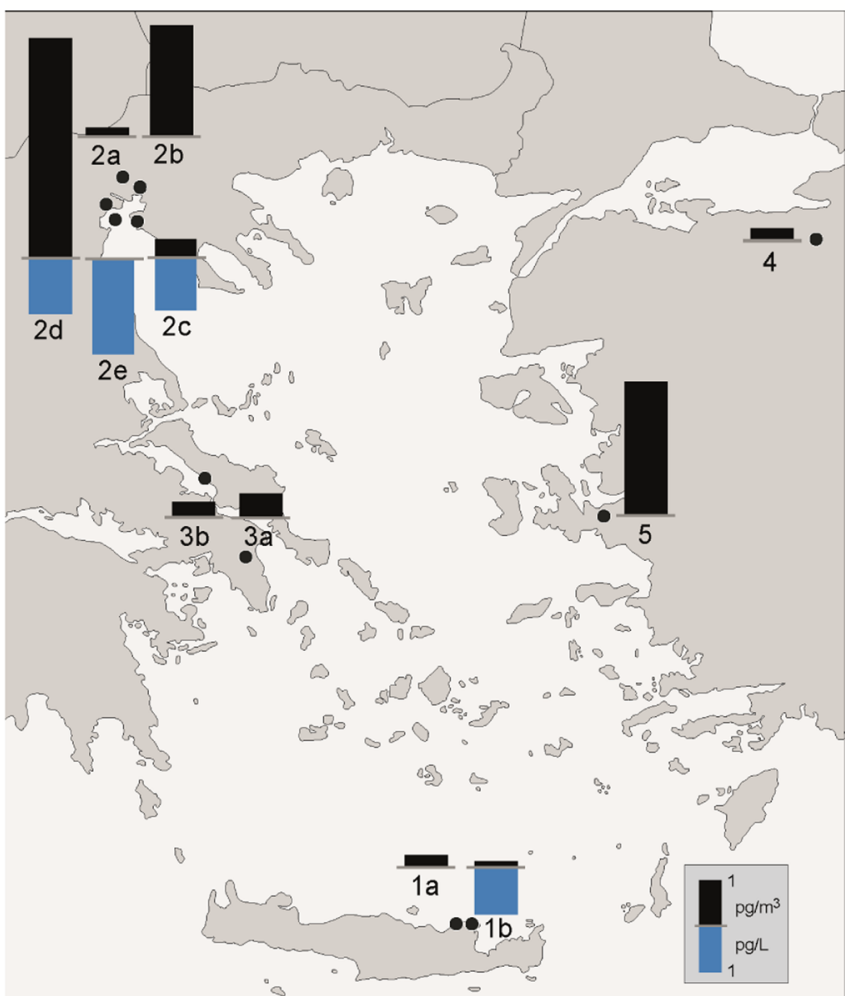

Fig. 1 Spatial trends of concentrations of a PAHs, $\mathbf{b}$ PCBs, $\mathbf{c}$ OCPs and $\mathbf{d}$ PBDEs in air (black; PAHs: $\mathrm{ng} \mathrm{m}^{-3}$, all others: $\mathrm{pg} \mathrm{m}^{-3}$ ) and water (blue; $\mathrm{pg} \mathrm{L}^{-1}$ ) at sites in the region (listed in Table 1) 
Table 1 Site characterisation, sampling periods, air temperature, wind speed [mean (min-max), hourly data] and number of samples collected in five areas around the Aegean Sea

\begin{tabular}{|c|c|c|c|c|c|c|c|}
\hline \multirow[t]{2}{*}{ Site no. } & \multirow[t]{2}{*}{ Name (sampling period in 2012) } & \multirow[t]{2}{*}{ Location } & \multirow[t]{2}{*}{ Type of site } & \multirow[t]{2}{*}{$\begin{array}{l}\text { Temperature } \\
\left({ }^{\circ} \mathrm{C}\right)\end{array}$} & \multirow[t]{2}{*}{$\begin{array}{l}\text { Wind speed } \\
\left(\mathrm{m} \mathrm{s}^{-1}\right)\end{array}$} & \multicolumn{2}{|c|}{$\begin{array}{l}\text { No. of } \\
\text { samples }\end{array}$} \\
\hline & & & & & & Air & Seawater \\
\hline $1 \mathrm{a}$ & Finokalia, Crete (5 July-2 August) & $35.3^{\circ} \mathrm{N} / 25.7^{\circ} \mathrm{E}$ & Remote coastal & $26.1(20.8-33.6)$ & $8.2(1.2-13.4)$ & 1 & \\
\hline $1 \mathrm{~b}$ & Selles Beach, Crete (3 July-2 August) ${ }^{a}$ & $35.2^{\circ} \mathrm{N} / 25.4^{\circ} \mathrm{E}$ & Remote coastal & $28.2(22.4-34.5)$ & $4.8(0.6-7.7)$ & $4^{\mathrm{b}}$ & $4^{\mathrm{c}}$ \\
\hline $2 \mathrm{a}$ & Neochorouda (2-30 July) & $40.6^{\circ} \mathrm{N} / 22.9^{\circ} \mathrm{E}$ & Suburban & $28.9(20.7-38.9)$ & $2.2(1.2-4.8)$ & 1 & \\
\hline $2 b$ & Thessaloniki, Agia Sophia (3-31 July) & & Urban & $29.5(23.3-36.9)$ & $1.5(0.7-3.4)$ & 1 & \\
\hline $2 \mathrm{c}$ & Thermaikos Gulf, Michaniona (2-30 July) & $40.5^{\circ} \mathrm{N} / 22.8^{\circ} \mathrm{E}$ & Residential coastal & n.d. & n.d. & 1 & 2 \\
\hline $2 d$ & $\begin{array}{l}\text { Thermaikos Gulf, Loudias River } \\
\text { estuaries (3-31 July) }\end{array}$ & $40.5^{\circ} \mathrm{N} / 22.7^{\circ} \mathrm{E}$ & Remote coastal & $29.3(21.8-38.7)$ & $1.6(0.8-3.7)$ & 1 & $2^{d}$ \\
\hline $2 \mathrm{e}$ & Thermaikos Gulf mussel cultivation & & Remote marine & n.d. & n.d. & & $2^{\mathrm{e}}$ \\
\hline $3 a$ & Athens, Demokritos (1-29 July) & $38.0^{\circ} \mathrm{N} / 23.8^{\circ} \mathrm{E}$ & Suburban & $29.1(20.7-40.5)^{\mathrm{f}}$ & $1.7(<0.4-5.1)^{\mathrm{f}}$ & 1 & \\
\hline $3 b$ & Politikos, Euboea (1-29 July) & $38.4^{\circ} \mathrm{N} / 24.2^{\circ} \mathrm{E}$ & Rural & n.d. & n.d. & 2 & \\
\hline 4 & Nilüfer, Bursa (2 July-13 August) & $40.2^{\circ} \mathrm{N} / 29.1^{\circ} \mathrm{E}$ & Suburban, rural & $26.2(15.3-36.2)$ & $0.9(<0.4-5.4)$ & 1 & \\
\hline 5 & Gülbahçe (2-31 July) & $38.3^{\circ} \mathrm{N} / 26.6^{\circ} \mathrm{E}$ & Rural & $28.9(21.6-36.5)$ & $5.6(<0.4-11.3)$ & 2 & \\
\hline
\end{tabular}

${ }^{\text {a }}$ Passive water sampling 3 July-2 August, passive and active air sampling 2-13 July

${ }^{\mathrm{b}}$ At three localities within $2800 \mathrm{~m}$ along shore

${ }^{\mathrm{c}}$ At two localities within $1400 \mathrm{~m}$ along shore

$\mathrm{d} \approx 100 \mathrm{~m}$ off shore

$\mathrm{e} \approx 1500 \mathrm{~m}$ off shore

${ }^{\mathrm{f}} 1-18$ July only

environment) according to the procedure reported by Booij et al. 2002. Before exposure, samplers were stored (at $-20{ }^{\circ} \mathrm{C}$ ) and transported to the field in amber glass $100-\mathrm{ml}$ vials with a screw cap with a stainless steel liner. SR passive samplers were deployed for 28 days in water mounted on stainless steel wire holders at 1-m depth using buoy and rope. After exposure, samplers were transported in original vials in a cooling box to the laboratory and stored at $-20^{\circ} \mathrm{C}$.

\section{Air/water fugacity ratio}

For fugacity ratio calculation (diffusive air-sea exchange, see "Air-sea diffusive gas exchange calculations") gas-phase concentrations, $c_{\mathrm{a}}$, were derived (Eq. 1) from the PAS concentrations using the particulate mass fraction of the contaminants, $\theta$, which were determined simultaneously by two pairs of high-volume gas and particulate phase AAS (above, mean of two values listed in Table S3).

$c_{\mathrm{a}}=c_{\mathrm{PAS} 28 \mathrm{~d}} \times(1-\theta)$

Sampling frequencies were 12 hourly for gaseous and total particulate fractions and 24-48 hourly for size-resolved particulate fractions.

Meteorological parameters (air temperature, humidity, wind direction and velocity) were also measured (Table 1).
Fugacity ratios from air and seawater can be derived for three sites i.e. $1 \mathrm{~b}, 2 \mathrm{c}$ and $2 \mathrm{~d}$ (Table 1).

\section{Chemical analyses}

All instrumental analyses were done in the same lab using identical methods. PUFs and SRs were extracted with DCM and methanol, respectively, in an automatic extractor (Büchi B-811). Surrogate recovery standards (D8-naphthalene, D10phenanthrene and D12-perylene, PCB congeners 30 and 185, ${ }^{13} \mathrm{C}$-labelled BDE congeners 28, 47, 99, 100, 153, 154, 183 and 209) were spiked on PAS PUFs prior to extraction. SRs were brushed before extraction to remove biofouling from the surface. Surrogate recovery standards (D8-naphthalene, D10phenanthrene, D12-perylene and PCB185) were added on SRs prior to extraction (Soxhlet, methanol, $8 \mathrm{~h}$ ).

Volume reduced extracts were split into two portions, for PAH analysis (10 \%) and analysis of PCBs, OCPs and PBDEs (90\%).

For the PAHs analysis, the extract was cleaned up on a silica column, eluted $(10 \mathrm{~mL} n$-hexane followed by $20 \mathrm{~mL}$ DCM), concentrated and transferred into an insert in a vial. Terphenyl was added as syringe standard. Gas chromatography-mass spectrometry (GC-MS) analysis was performed on 7890A GC (Agilent, USA), equipped with a DB5-MSUI column (Agilent, J\&W, USA) and coupled to a 7000B MS 
(Agilent, USA), operated in EI+ mode with selected ion recording (SIR). Injection was $1 \mu \mathrm{L}$ splitless at $280^{\circ} \mathrm{C}$, with $\mathrm{He}$ as carrier gas $\left(1.5 \mathrm{~mL} \mathrm{~min}^{-1}\right)$. The $\mathrm{GC}$ programme was $80^{\circ} \mathrm{C}$ ( $1 \mathrm{~min}$ hold), then $15^{\circ} \mathrm{C} \mathrm{min}^{-1}$ to $180{ }^{\circ} \mathrm{C}$, followed $5^{\circ} \mathrm{C} \mathrm{min}{ }^{-1}$ to $310^{\circ} \mathrm{C}$ (20 min hold). For PBDE, PCB and OCP analysis, the extract was cleaned up on $\mathrm{H}_{2} \mathrm{SO}_{4}$ modified (44 \% w/w) silica column, eluted (40 $\mathrm{mL} \mathrm{DCM} / n$-hexane mixture $1: 1$ ), concentrated and transferred into an insert in a vial. ${ }^{13} \mathrm{C}$ BDEs 77 and 138, and PCB 121 were added as syringe standards. For PBDEs, HRGC/HRMS analysis was performed on a 7890A GC (Agilent, USA) equipped with an RTX-1614 column (Restek, USA) and coupled to an AutoSpec Premier MS (Waters, Micromass, UK), operated in EI+ mode at the resolution of $>10,000$. For BDE 209, the MS resolution was set to $>5000$. Injection was splitless $2 \mu \mathrm{L}$ at $280^{\circ} \mathrm{C}$, with $\mathrm{He}$ as carrier gas $\left(1 \mathrm{~mL} \mathrm{m^{-1 }}\right)$. The $\mathrm{GC}$ temperature programme was $80^{\circ} \mathrm{C}$ ( $1 \mathrm{~min}$ hold $)$, then $20^{\circ} \mathrm{C} \mathrm{min}^{-1}$ to $250^{\circ} \mathrm{C}$, followed by $1.5^{\circ} \mathrm{C} \min ^{-1}$ to $260{ }^{\circ} \mathrm{C}(2 \mathrm{~min}$ hold $)$ and $25^{\circ} \mathrm{C} \mathrm{min}{ }^{-1}$ to $320^{\circ} \mathrm{C}$ (4.5 min hold). For PCBs and OCP GC-MS/MS analysis was performed on a 7890A GC (Agilent, USA) equipped with an HT8 column (SGE, USA) and coupled to a 7000B MS (Agilent, USA), operated in EI+ MRM. Injection was splitless $3 \mu \mathrm{L}$ at $280^{\circ} \mathrm{C}$, with $\mathrm{He}$ as carrier gas $\left(1.5 \mathrm{~mL} \mathrm{~min}^{-1}\right)$. The $\mathrm{GC}$ temperature programme was $80{ }^{\circ} \mathrm{C}$ ( 1 min hold $)$, then $40{ }^{\circ} \mathrm{C} \mathrm{min}{ }^{-1}$ to $200{ }^{\circ} \mathrm{C}$, and finally $5^{\circ} \mathrm{C} \min ^{-1}$ to $305^{\circ} \mathrm{C}$.

Quality assurance/quality control Recoveries of PAHs in PAS were 79-129\%, except for dibenz(a,h)anthracene, which was $150 \%$ in PASs and 61-101\% in SRs, except for acenaphthylene, anthracene and benzo(a)pyrene, which were 29, 53 and $49 \%$, respectively. Recoveries of PCBs and OCPs from PASs were $80-88 \%$ and $71-114 \%$, respectively, while recoveries from SRs were 101-111\% and 77-129 \%, respectively. Recoveries of PBDEs were 79-159 \% from PASs, and 60-107\% from SRs, except for BDE209, which was poorly recovered (24\% from PASs and $6 \%$ from SRs on average). Recovery factors were not applied to calculate PAH, PCB and OCP results, but were applied for all PBDE results. Recovery of surrogates (deuterated substances, see above) varied from 88 to $100 \%$ for PCB and from 72 to $102 \%$ for PAHs. Field blanks for various types of sample were collected along with the samples. For each site separately, the mean of one to four PAS field blank values was subtracted from the air sample values.

Values below the mean plus three standard deviations of the field blank values were considered below limit of quantification (LOQ). Field blank values of most analytes in air samples were lower than the instrument limits of quantification (ILOQ) at most sites. Highest LOQs for analytes in PASs, up to 0.028 and $0.13 \mathrm{ng} \mathrm{m}^{-3}$, resulted for acenaphthene (ACE) and fluorene (FLN), respectively, and up to 24, 8.6 and $1.2 \mathrm{pg} \mathrm{m}^{-3}$ resulted for $\mathrm{PeCB}, \beta-\mathrm{HCH}$ and $\gamma-\mathrm{HCH}$, respectively. Higher LOQs for analytes in the high-volume AASs, up to 0.0008 and $0.011 \mathrm{ng} \mathrm{m}^{-3}$ resulted for FLN and phenanthrene (PHE), respectively, and up to $0.8 \mathrm{pg} \mathrm{m}^{-3}$ resulted for $\alpha$ - and $\gamma$-HCH. The ILOQs were calculated on three times the instrument limit of detection, which is calculated as three times the chromatogram baseline noise level. The respective ILOQs for various types of sample are listed in the SM, Table S2.

Free dissolved water concentrations of analytes in SRs were calculated from amounts accumulated in SRs using the exponential uptake model described in Smedes (2007). The required sampling rates were estimated by fitting PRC dissipation data from sampler to the model described by Booij and Smedes 2010.

\section{Air-sea diffusive gas exchange calculations}

State of phase equilibrium is addressed by fugacity calculation, based on the Whitman two-film model (Liss and Slater 1974; Bidleman and McConnell 1995). The fugacity ratio (FR) is calculated as:

$$
\mathrm{FR}=f_{\mathrm{a}} / f_{\mathrm{w}}=c_{\mathrm{a}} R T_{\mathrm{a}} /\left(c_{\mathrm{w}} H_{\mathrm{Tw}, \text { salt }}\right)
$$

with gas-phase concentration $c_{\mathrm{a}}\left(\mathrm{ng} \mathrm{\textrm {m } ^ { - 3 }}\right)$, dissolved aqueous

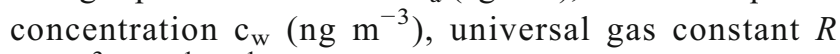
$\left(\mathrm{Pa} \mathrm{m} \mathrm{mol}^{-1} \mathrm{~K}^{-1}\right)$, water temperature and salinity corrected Henry's law constant $H_{\mathrm{Tw} \text {,salt }}\left(\mathrm{Pa} \mathrm{m}^{3} \mathrm{~mol}^{-1}\right)$ and air temperature $T_{\mathrm{a}}(\mathrm{K})$, which was measured continuously on site. The water temperature was assumed to be $0.5 \mathrm{~K}$ lower than the air temperature, throughout, based on discontinuous measurements at site $1 \mathrm{~b}, 10-30 \mathrm{~cm}$ below the surface, which covered morning, noon, evening and night time measurements. Values $0.3<\mathrm{FR}<3.0$ are conservatively considered to not safely differ from phase equilibrium, as propagating from the uncertainty of the Henry's law constant, $H_{\mathrm{Tw} \text {,salt }}$, and measured concentrations (e.g. Bruhn et al. 2003; Castro-Jiménez et al. 2012; Zhong et al. 2012). This conservative uncertainty margin is also adopted here, while FR $>3.0$ indicates net deposition and $\mathrm{FR}<0.3$ net volatilisation. The diffusive air-seawater gas exchange flux ( $F_{\text {aw }}, \mathrm{ng} \mathrm{m}^{-2}$ day $^{-1}$ ) is calculated according to the Whitman two-film model (Bidleman and McConnell 1995; Schwarzenbach et al. 2003):

$F_{\mathrm{aw}}=k_{\mathrm{ol}}\left(c_{\mathrm{w}}--c_{\mathrm{a}} R T_{\mathrm{a}} / H_{\mathrm{Tw}, \text { salt }}\right)$

with air-water gas exchange mass transfer coefficient $k_{\mathrm{ol}}$ $\left(\mathrm{m} \mathrm{h}^{-1}\right)$, accounting for resistances to mass transfer in both water $\left(k_{\mathrm{w}}, \mathrm{m} \mathrm{h}^{-1}\right)$ and air $\left(k_{\mathrm{a}}, \mathrm{m} \mathrm{h}^{-1}\right)$ (see Bidleman and McConnell 1995; Zhong et al. 2012; and references therein). Substance property data are taken from the literature (references listed in the SM, S1).

Sampler uptake kinetics and the half-time of equilibration of organics dissolved in water in SRs is substance dependent. For most substances the derived concentrations reflect the 
mean over the entire exposure period, but for $\mathrm{HCH}$ and some two- to three-ring PAHs only the mean of the last 12-24 days of the exposure period. Substances which, accordingly, were determined in air and water simultaneously only for a short period (air sampling terminated 14 days before water sampling), i.e. HCH isomers, NAP, ACE, ACY and FLN were excluded from diffusive air-sea exchange calculations.

\section{Results and discussion}

\section{Air mass origin}

The predominant origin of air masses during the sampling campaign was central, eastern and southeastern Europe. This is shown as the distribution of residence time of air masses in Fig. S1. This analysis is based on re-analysis data and back trajectory modelling (FLEXPART model; Stohl et al. 1998).

During 2-11 July 2012 the Aegean was mostly influenced by northerly, in its northern part easterly advection as part of a cyclonic system, which moved from western Russia to Romania. Under the influence of a strong westerly flow towards Europe, the flow in the northern part of the Aegean switched to westerly during the night 11-12 July, such that air which had been residing over the SW Balkans was advected, as well as air from beyond, i.e. central Italy, the NW Mediterranean Sea and the Iberian Peninsula. Air from central Europe flew to the Aegean until the night of 17-18, and from the northeast thereon. Then, for a few days, air arrived in the Aegean from central Europe, directed (counter-clockwise) around a cyclonic system above Italy. From the evening of 27 July until the beginning of August, eastern flow arrived in the Aegean. The mean air temperatures ranged $26-29^{\circ} \mathrm{C}$ in the study area with higher temperature maxima at the Thessaloniki and Athens sites (Table 1). No precipitation occurred during the measurement period with only one exception, namely on 30 July at the Thermaikos Gulf sites.

\section{Concentration levels}

Mean concentrations of PAHs, PCBs, OCPs and PBDEs found in near-ground air and surface seawater are shown in Figs. 1, 2 and 3. Concentrations of the individual substances targeted are provided in Tables S4-5.

\section{Levels, trends and patterns of PTS in near-ground air}

Polycyclic aromatic hydrocarbons The significance of local primary sources and, hence, spatial variation is higher for PAHs than for halogenated PTS (Lammel et al. 2010; Lammel 2015). In this study, we found a trend of increasing PAH levels from remote to rural and residential sites, with the
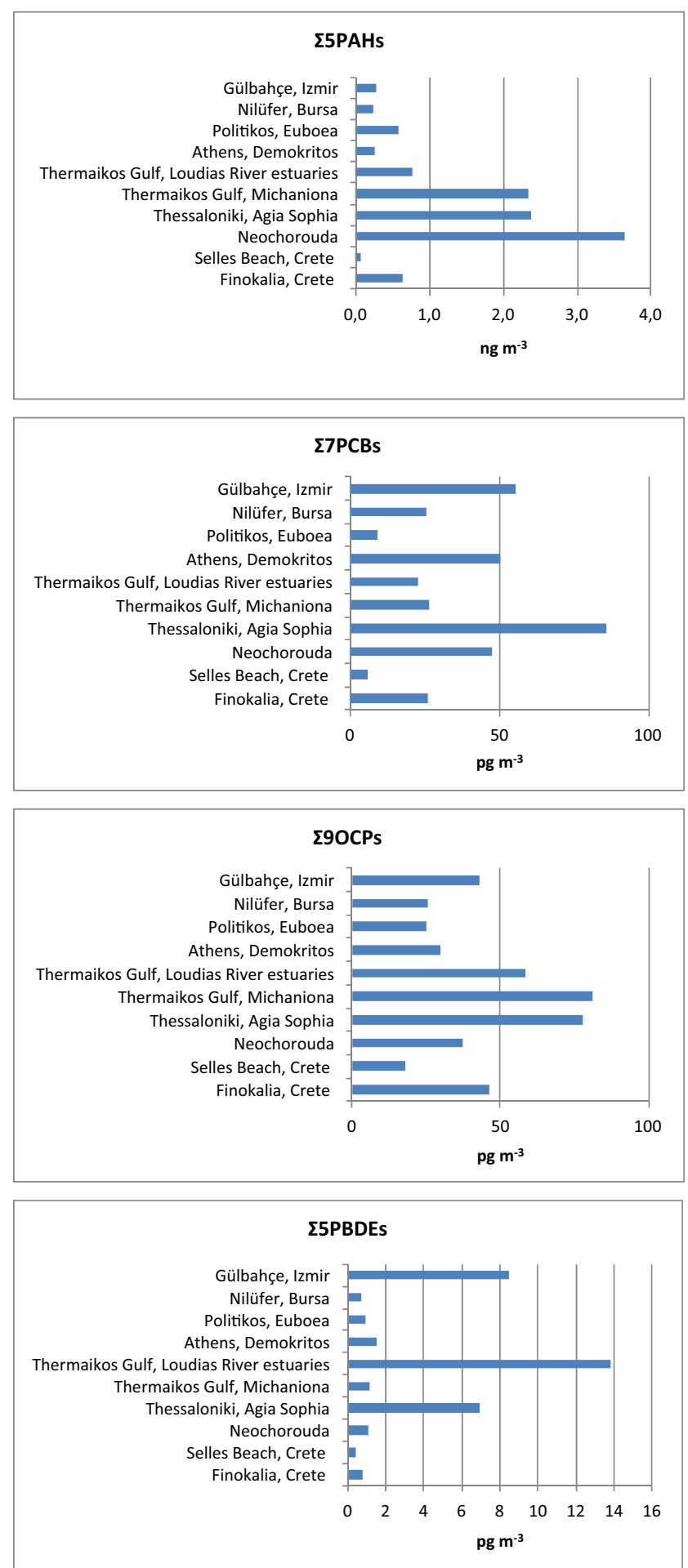

Fig. 2 Sum concentrations of PAHs, PCBs, OCPs and PBDEs found in the air at various sites across the Aegean Sea

highest levels occurring at urban and residential sites in the Thessaloniki area (Figs. 1 and 2, Tables 2, S4-S5). PAH patterns in air seem to be quite dissimilar across sites (mean correlation coefficient $r=0.60$; Table S6a). However, because of major PAHs commonly found not being included in this 

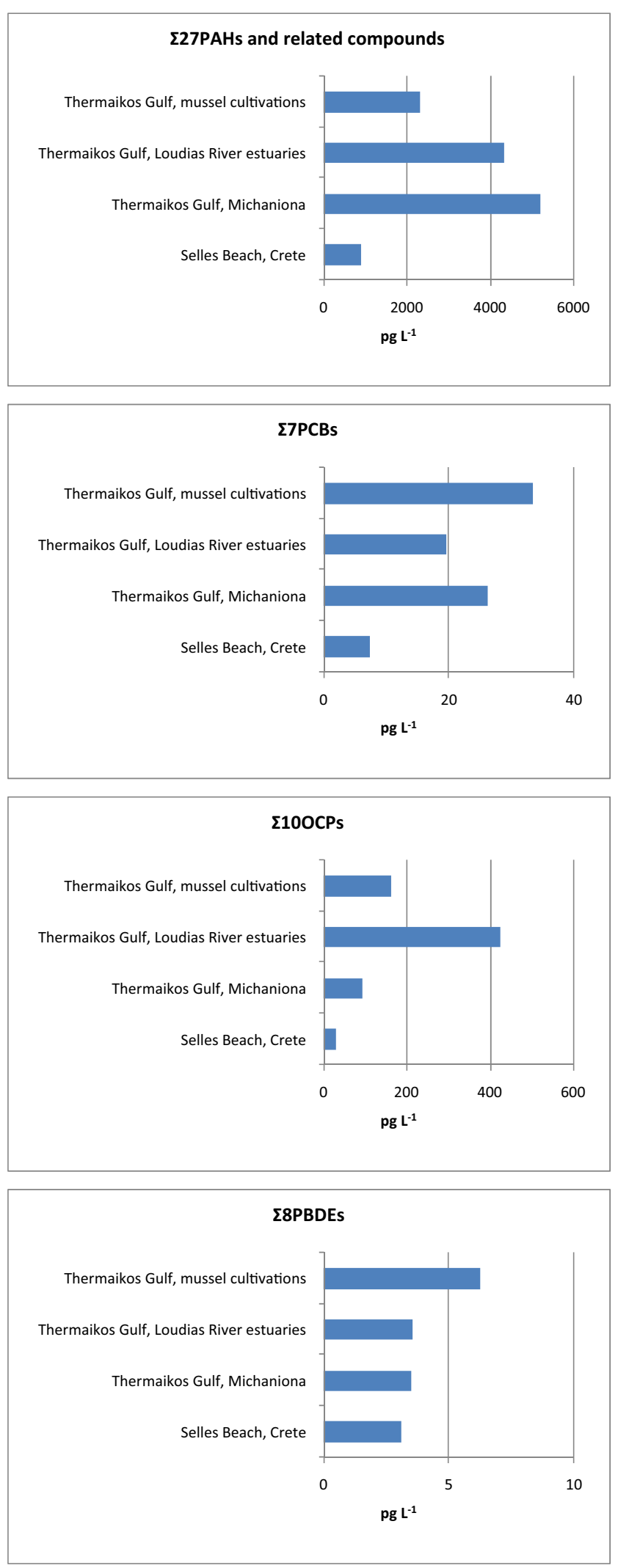

Fig. 3 Sum concentrations of PAHs and related compounds, PCBs, OCPs and PBDEs found in surface sea water at coastal sites across the Aegean Sea analysis (but only five substances), a conclusion on source contributions would not be justified (Dvorská et al. 2012). Indeed, the similarity across sites is high (mean $r=0.93$ ) if PAH patterns are compared across sites on a pg basis (i.e. PAS results not divided by effective sampling volume; Table S7 for 10 PAHs). Then, just some dissimilarity from the prevailing pattern is indicated for one site, Bursa $(r=$ 0.74-0.81). This can be explained by the inclusion of substances significantly partitioning to the particulate phase in the targeted substance class, namely FLT and PYR (as shown in the region; Terzi and Samara 2004, besides others). Gasparticle partitioning of semivolatiles, and hencethe effective sampling volume, depends not only on temperature (similar across sites) but also on the particulate phase chemical properties, which was certainly dissimilar across site types and across sites of same type. This is related to the processes determining gas-particle partitioning of semivolatiles, which are dependent on particulate phase chemical properties, such as organic and black carbon abundances (Lohmann and Lammel 2004). The PAH levels at the remote sites $1 \mathrm{a}-\mathrm{b}$ are similar to those observed at a high mountain site in 2006 (Moussala, SW Bulgaria) and in the open eastern Mediterranean Sea in 2010, but lower than those observed in the Aegean Sea, eastern Mediterranean Sea, and Black Seas in 2006 (ship measurements; Table 2). Local primary sources should also explain the levels found in Aliartos, central Greece, in 2006 and a suburban site in the Izmir area in 2003-2004, which were more than one order of magnitude higher (Table 2). The concentrations reported from rural sites in the Republic of Macedonia (Stafilov et al. 2011; Table 2) are based on the same sampling and analysis methods as our study, but $V_{28 \mathrm{~d}}=100 \mathrm{~m}^{3}$ was assumed throughout, which is up to a factor of 6 below values of $V_{28 d}$ used in here. This may explain the high levels reported from there.

The levels of PAHs at the urban/residential sites in the area of Thessaloniki $(2 \mathrm{a}-\mathrm{c})$ are low among the range of levels reported for urban and rural sites in Greece for gaseous PAHs collected by active sampling (Manoli et al. 2011, and references herein). For PAHs and HCHs, the differences span more than one order of magnitude in some cases (Table 2). Partly, this discrepancy might be explained by overestimated sampling efficiencies (discussed in section S2).

Polychlorinated biphenyls PCBs in the Thessaloniki, Athens and Izmir areas (sites 2a, 3a and 5), as well as in the Bursa area, NW Turkey, in 2008-2009 (Birgül and Taşdemir 2011), are found (only) a factor of 2 higher than at the remote sites $1 \mathrm{a}$ and $1 \mathrm{~b}$. This points to the significance of PCB sources in urban areas for regional distribution discussed previously (Diamond et al. 2010). Urban-to-rural PCB gradients were also observed in the Mediterranean (Mandalakis et al. 2002; Gasić et al. 2010). PCB patterns in air are almost identical across all sites in the region (Table S6a). The same is found 
Table 2 Overview of contaminants' mean concentrations observed in near-ground air of the region in recent years $\left(\mathrm{PAHs}, \mathrm{ng} \mathrm{m}^{-3}\right.$; all other, $\left.\mathrm{pg} \mathrm{m}^{-3}\right)$. Limited number of individual substances included for the sake of comparability

\begin{tabular}{|c|c|c|c|c|c|c|}
\hline Site, year, reference & $\Sigma \mathrm{PAH}_{5}{ }^{\mathrm{a}}$ & $\Sigma \mathrm{PCB}_{7}^{\mathrm{b}}$ & HCB & $\Sigma \mathrm{HCH}^{\mathrm{c}}$ & $\Sigma D D T s^{\mathrm{d}}$ & $\Sigma \mathrm{PBDE}_{3}{ }^{\mathrm{e}}$ \\
\hline \multicolumn{7}{|l|}{ Remote } \\
\hline Crete, remote (summer 2012, this work, sites 1a-b) & $0.070-0.63$ & $5.8-25.9$ & $8.1-19$ & $3.4-15.8$ & $3.2-6.3 / 0.40-0.78$ & $0.4-0.78$ \\
\hline Crete, remote (summer 2006; Iacovidou et al. 2009) & & $8.4^{\mathrm{f}}$ & & & & 1.2 \\
\hline Thessaloniki area, coastal remote (summer 2012, this work, site 2d) & 0.76 & 22.6 & 11 & 11.5 & & 13.8 \\
\hline SW Bulgaria, remote, high mountain (Moussala, summer 2006; Halse et al. 2011) & 0.63 & 10.3 & & 55.9 & 19.7 & \\
\hline Aegean Sea (cruise, summer 2006; Castro-Jiménez et al. 2012; Berrojalbiz et al. 2014) & $5.5^{\mathrm{f}}$ & $69-234$ & $11-106$ & $39-85$ & & \\
\hline Black Sea (cruise, summer 2006; Castro-Jiménez et al. 2012) & $7.4^{\mathrm{g}}$ & & & & & \\
\hline $\begin{array}{l}\text { C and E Mediterranean (cruises, June 2006, May 2007; Castro-Jiménez et al. 2012; } \\
\text { Berrojalbiz et al. 2014) }\end{array}$ & 4.7 & $29-234$ & $5-178$ & $<3-155$ & & \\
\hline E Mediterranean (cruise summer 2010; Mulder et al. 2013, 2014) & 0.61 & 3.3 & 6.0 & & 1.4 & 4.3 \\
\hline \multicolumn{7}{|l|}{ Rural, residential } \\
\hline Thessaloniki area, residential (summer 2012, this work, sites 2a, 2c) & $2.33-3.64$ & $26.7-47.5$ & $9.9-10$ & $9.3-10.4$ & $8.4-51 / 0.56-1.12$ & \\
\hline Athens, suburban (summer 2012, this work, site 3a) & 0.25 & 50.2 & 10.2 & 9.7 & 4.7 & 1.5 \\
\hline Central Greece, rural (summer 2012, this work, site 3b) & 0.58 & 9.0 & 6.7 & 4.8 & 7.0 & 0.9 \\
\hline Izmir, suburban, W Turkey, whole year 2003-2004 (Demircioglu et al. 2011) & 21.9 & & & & & \\
\hline W Greece, two rural sites, whole year 2000-2001 (Terzi and Samara 2004) & $2.9-13.8^{\mathrm{j}}$ & & & & & \\
\hline C Greece, rural (Aliartos, summer 2006; Halse et al. 2011) & 23.7 & 13.6 & & 54.0 & 228 & \\
\hline NW Turkey, semi-residential (summer 2012, this work, site 4) & 0.23 & 25.6 & 5.5 & 5.7 & 7.9 & 0.7 \\
\hline NW Turkey, semi-rural, full year 2008-09 (Birgül and Taşdemir 2011) & & 74 & & & & \\
\hline NW Turkey, rural, coastal, full year 2008-2009 (Yolsal et al. 2014) & & 80 & & & & \\
\hline W Turkey, rural (summer 2012, this work, site 5) & 0.27 & 55.3 & 12.3 & 13.8 & 12.8 & 8.5 \\
\hline Macedonia, two rural sites, summer 2007 (Stafilov et al. 2011) & & $24-174$ & $37-46$ & $101-182$ & $36-126$ & \\
\hline \multicolumn{7}{|l|}{ Urban, industrial } \\
\hline Thessaloniki area, urban (summer 2012, this work, site 2b) & 2.38 & 85.7 & 9.8 & 14.9 & $42.5 / 6.96$ & \\
\hline W Greece, urban site, whole year 2000-2001 (Terzi and Samara 2004) & $21.7^{\mathrm{h}}$ & & & & & \\
\hline Athens, urban, December 2006 (Mandalakis et al. 2009) & & & & & & 3.6 \\
\hline $\begin{array}{l}\text { Two sites in the suburban area of Athens, June and November } 2003 \\
\text { (Vasilakos et al. 2007) }\end{array}$ & $17.5-20.1^{\mathrm{h}}$ & & & & & \\
\hline Iraklion, semi-urban, 2006-2007 (Mandalakis et al. 2009) & & & & & & 10.7 \\
\hline Republic of Macedonia, four urban sites, summer 2007 (Stafilov et al. 2011) & & $74-278$ & $35-51$ & $165-3033$ & $106-246$ & \\
\hline Izmir, W Turkey, winter/summer 2005 (Pozo et al. 2009) & & $644 / 287$ & & $29 / 48$ & $51 / 60$ & \\
\hline Izmir, W Turkey, winter 2004 (Demircioglu et al. 2011) & 100 & & & & & \\
\hline Izmir, W Turkey, spring 2003 (Sofuoglu et al. 2004) & & 228 & & & 49 & \\
\hline Aliaga, W Turkey, all seasons 2009-2010 (Kaya et al. 2012) & 78 & 2560 & & & & \\
\hline Zonguldak, N Turkey, winter/summer 2007-2008 (Akyüz and Çabuk 2010) & $260 / 21$ & & & & & \\
\hline Konya, S Turkey, full year 2006-2007 (Ozcan and Aydin 2009) & 93 & 78 & & 520 & 130 & \\
\hline Bursa, NW Turkey, all seasons 2004-2005 (Taşdemir and Esen 2007) & 20 & & & & & \\
\hline Bursa, NW Turkey, full year 2008-2009 (Birgül et al. 2011; Yolsal et al. 2014) & $117^{\mathrm{h}}$ & 61 & & & & \\
\hline
\end{tabular}

${ }^{\text {a }}$ Sum of ACE, FLN, PHE, FLT and PYR

${ }^{\mathrm{b}} \mathrm{PCB} 28, \mathrm{PCB} 52, \mathrm{PCB} 101, \mathrm{PCB} 118, \mathrm{PCB} 153, \mathrm{PCB} 138$ and PCB180

${ }^{\mathrm{c}}$ Sum of $\alpha$ - and $\gamma-\mathrm{HCH}$

${ }^{\mathrm{d}}$ Sum of DDT and DDE isomers

${ }^{\mathrm{e}} \mathrm{Sum}$ of BDE47, BDE99 and BDE100

${ }^{\mathrm{f}}$ Without PCB28 and PCB138

${ }^{g}$ Without ACE

${ }^{\mathrm{h}}$ Without ACE and FLN

with slightly lower correlation coefficients if $\mathrm{PCB}$ patterns are compared across sites on a pg basis (Table S7). Selective photochemical degradability of the congeners (Mandalakis et al. 2003) would suggest that the pattern changes during transport from (urban) sources to the remote site, not confirmed here. 
Organochlorine pesticides The levels of $\mathrm{HCB}, \mathrm{HCHs}$ and DDX in air at the rural and residential sites $3 a-b, 4$ and 5 are not elevated against the remote sites, but similar. The highest concentrations of $\mathrm{HCB}$ and $\alpha-\mathrm{HCH}$ are actually found at the remote site $1 \mathrm{a}$ (Tables $\mathrm{S} 4 \mathrm{a}, \mathrm{S} 5$ ). The ratio $\alpha-\mathrm{HCH} / \gamma-$ $\mathrm{HCH}$ ranges widely, from 1.3 to 7.8. The lowest values of this ratio are observed at the urban sites $2 \mathrm{a}, \mathrm{b}$, close to what was previously found at site $2 \mathrm{~b}$ in summer for the particle-bound $\mathrm{HCH}$ isomers (Chrysikou and Samara 2009). The maximum $\alpha-\mathrm{HCH} / \gamma-\mathrm{HCH}$ ratio is observed at the remote site $1 \mathrm{a}$ (remote, 7.8) and may reflect the effect of the higher Henry coefficient (units of $\mathrm{Pa} \mathrm{m}^{3} \mathrm{~mol}^{-1}$ ) of $\alpha-\mathrm{HCH}$ in an environment where the atmospheric levels are dominated by the source re-volatilisation from surface seawater. OCP patterns in air are found highly correlated across all sites except the remote site 1a (also when compared on a pg basis, see Tables S6a and 7), which show different patterns, e.g. DDT/ DDX is the highest. This may also indicate substance selective sinks (dry deposition, photochemistry) or sources (revolatilisation from the sea surface) active during transport from continental sources to Crete. The prevailing spatial homogeneity of the concentration levels confirms the perception of long-lived pollutants undergoing even distribution within a region, or even being dominated by LRT from outside the region. In general, they are lower than reported previously from the same type of sites in the region (though only few measurements available; Table 2). At the remote sites, HCB and DDX levels are found similar to ship measurements in 2010 in the eastern Mediterranean (Mulder et al. 2013), while DDX was much lower than at a remote high mountain site in SW Bulgaria (Halse et al. 2011; Table 2). Furthermore, DDX had been reported very high at a rural site in central Greece, Aliartos, in 2006 (Halse et al. 2011; Table 2).

A fairly consistent regional distribution with rather small urban-to-rural/residential concentration gradients was found for HCB, HCHs and DDX, and small rural/ residential-to-remote gradients for $\mathrm{HCB}$ and $\mathrm{HCHs}$. Similar conclusions were drawn for $\mathrm{HCB}$ and $\mathrm{HCH}$ based on PAS across the entire European continent in 2006-2007 (Halse et al. 2011).

I n c o n trast, D D X s, namely $p, p^{\prime}-$ dichlorodiphenyldichloroethylene ( $p, p^{\prime}$-DDE) and also $o, p^{\prime}$ DDT, were elevated in air at the urban and coastal sites in the Thermaikos Gulf (2b, 2c and 2d, Fig. 2, Table S4a), as well as in seawater (namely $p, p^{\prime}$-DDE and $p, p^{\prime}$-DDD, sites $2 \mathrm{c}$ and 2 d, Fig. 2, Table S4b). The fraction of parent DDT among the DDX compounds is low in both air and seawater (ranges $0.03-0.43$ and $0.01-0.37$, respectively). This indicates the absence of any fresh DDT input to the marine environment of the Aegean. DDT had been banned in the 1970s and 1980s (Pacyna et al. 2003). However, the surface seawater of the eastern Mediterranean is expected to be a source for DDT since the 1980s (Stemmler and Lammel 2009).
Polybrominated diphenylethers BDE levels in air are found at sites $2 \mathrm{~b}$ (urban), 2d (remote coastal) and 5 (rural) and are found about one order of magnitude higher than at the other sites (Figs. 1d and 2, Tables S4a, S5). While the high levels correspond to what was reported in 2006-2007 from Greek urban and semi-urban sites (Mandalakis et al. 2009; Table 2), the lower levels (sites 1a, 1b, 2a, 2c, 3b and 4; Fig. 2, Tables S4a, S5) are below earlier observations, including one from Finokalia, i.e. site 1a (Iacovidou et al. 2009; Table 2). The measured concentrations might be underestimated due to overestimated sampling efficiencies (discussed in section S2) for some sites (2a, 2b, 3a and 4). Surprisingly, while at most Greek sites, the most abundant congener was BDE47 followed by BDE99; it was BDE28 at the Greek site $3 b$ and at the two Turkish sites. PBDE patterns in air are obviously similar among most Greek sites (even identical, $r=1.0$ between sites 1 and 2, and sites 2 and 3), but dissimilar among the Turkish sites and across the countries (Table S6a). When PBDE PAS results are expressed as ng rather than as $\mathrm{ng} \mathrm{m}^{-3}$ (Table $\mathrm{S} 7$ ), correlation coefficients are not higher, but lower. This is noteworthy, as the targeted PBDEs are significantly partitioning to the particulate phase (Chen et al. 2006; Cetin and Odabasi 2008; Su et al. 2009), similar to targeted PAHs, for which correlation coefficients are higher when based on ng (above). Observations suggest that PBDE phase partitioning is largely determined by adsorption (Cetin and Odabasi 2008; Su et al. 2009). This suggests that different aerosol chemical composition (across sites) could hardly affect partitioning, in agreement with the finding here (Tables S6a and S7). However, predictability of PBDE partitioning is low, as most congeners are not expected to be in phase equilibrium as a consequence of high $K_{\mathrm{oa}}$ values (Cetin and Odabasi 2008). Therefore, phase partitioning of individual congeners could vary across sites and in different air masses at the same site even for similar temperatures and similar particulate phase chemical properties, determined by aging.

\section{Levels and trends in surface seawater}

Mean levels of the sum concentrations of PAHs and related compounds, PCBs, OCPs and PBDEs found in surface seawater at four coastal sites across the Aegean Sea are presented in Fig. 3 (for individual substances targeted, see Table S4).

Pollutant levels and spatial trends The concentrations of PAHs, PCBs, HCHs and DDX compounds in surface seawater of the Thermaikos Gulf are a factor of 2-10 higher than at the Cretan site, $1 \mathrm{~b}$ (Figs. 1 and 3, Table S4b). This concentration gradient is exceeding one order of magnitude for some PAHs, notably PHE, RET, BBN, BGF, CHR and BEP. This may reflect direct discharges from nearby urban activities and from ships, or photochemical degradation during atmospheric 
transport to the remote site. A similar north-south gradient of PCB was observed in 2006-2007, with a concentration span of two to four between the northern and southern Aegean Sea (dissolved fractions; Berrojalbiz et al. 2011).

For PeCB, HCB and PBDEs, no significant difference in seawater concentrations is found across sites.

The spatial variation of seawater pollution across the three Thermaikos Gulf sites is considerable for PAHs (highest at the residential coastal site 2c, Michaniona) and DDX (highest at the remote site 2d, Loudias River estuaries; Figs. 1 and 3, Table S4b). The highest OCP levels at the Loudias River plume imply influence from agricultural activities, whereas the highest levels of PCBs and PBDEs at the off-shore site $2 \mathrm{e}$ (located $1.4 \mathrm{~km}$ from the coastal site $2 \mathrm{~d}$ ) may indicate a shift of contaminant partitioning from particle-bound to dissolved, corresponding to a negative gradient of suspended particulate matter concentration, or influence from shipping activities.

Comparison with previous observations Our data represent a snapshot in time. The PAH levels in the Thermaikos Gulf are significantly lower than those found in the northern Aegean Sea in 1997 (10-30 $\mathrm{n} \mathrm{L} \mathrm{L}^{-1}$, however, unclear whether total or dissolved concentrations; UNEP 2002). PCB concentrations in two samples of seawater collected in the southern Aegean Sea (close to Crete) was lower in $2006-2007, \Sigma \mathrm{PCB}_{7}=2.6$ and $3.7 \mathrm{pg} \mathrm{L}^{-1}$, in contrast to $7.5 \mathrm{pg} \mathrm{L}^{-1}$ at the Cretan site in 2012. PCB in two seawater samples collected in the northeastern and central Aegean Sea 2006-2007 was somewhat lower, 7.3 and $13.8 \mathrm{pg} \mathrm{L}^{-1}$ (Berrojalbiz et al. 2011), than that found in 2012 in the Thermaikos Gulf (19.6-33.4 $\mathrm{pg} \mathrm{L}^{-1}$; Table S4b). Dissolved $\Sigma \mathrm{PCB}_{7}$ was also lower, $13.1 \mathrm{pg} \mathrm{L}^{-1}$, in 1987 in surface seawater of the southern Aegean, Cretan and Ionian Seas (Schulz-Bull et al. 1997). HCB is found consistently higher by a factor of about 5 than in the northern Aegean Sea in 2006-2007 (dissolved phase; Berrojalbiz et al. 2011). $\beta$ - and $\gamma-\mathrm{HCH}$ concentration at site $1 \mathrm{~b}$ are also higher than in 2006-2007, namely by a factor of 3 and 5, respectively.

Concentration levels of OCPs, PCBs and PAHs in seawater of the Thermaikos Gulf have exhibited a considerable decrease during the last two decades (Kamarianos et al. 2002). Nevertheless, several PTSs have been recently detected in sediments from Thermaikos Gulf including $p, p^{\prime}$-DDE, $\alpha$ and $\beta-\mathrm{HCH}, \mathrm{PCBs}$ (mainly the congeners 138, 101, 28 and 180; Terzopoulou and Voutsa 2011), PBDEs (Dosis et al. 2011), and PAHs (IKYDA 2010).

Contaminant patterns The ratio DDT/DDX, indicative for aging, equals 0.37 in seawater of the Cretan coast, site $1 \mathrm{~b}$, and much less, $0.01-0.05$, in the Thermaikos Gulf. This may point to some influence of long-range transported DDT in the southern Aegean Sea as opposed to the Thermaikos Gulf environment. PAH and PBDE patterns in seawater are highly consistent across all sites (Table S6b). PCB patterns in seawater are consistent, too, but less than in air (Table S6a, b). However, there is also a difference in the PCB pattern along the off-shore gradient. The OCP pattern at the remote site $1 \mathrm{~b}$ is very different from the patterns found in the Thermaikos Gulf. The ratio $\alpha-\mathrm{HCH} / \gamma-\mathrm{HCH}$ ranges $0.4-2.2$ in seawater, lower than in air. This is in line with the difference in Henry coefficients higher (in units of $\mathrm{Pa} \mathrm{m}^{3} \mathrm{~mol}^{-1}$ ) for $\alpha$ - than $\gamma-\mathrm{HCH}$. Along the off-shore gradient $\alpha-\gamma-\mathrm{HCH}$ almost triples from 0.4 to 1.1 , indicating minimal values in freshwater of the area. This might be related to air-sea exchange of the isomers, not effective in or close to the estuary.

\section{Air-sea gas exchange}

The direction of air-sea exchange was derived for three sites in two areas, $1 \mathrm{~b}$ (Crete), 2c and 2d (Thermaikos Gulf). The threering PAHs ACE, FLN and PHE are found volatilisational (i.e. upward net flux) in the Thermaikos Gulf (no measurement at the Cretan coast) (Fig. 4). Such a result is not unexpected for coastal waters in the vicinity of strong primary emissions and had been observed before in coastal waters of the northeastern USA (Lohmann et al. 2011) and even in the open southeastern Mediterranean Sea in spring 2007 (Castro-Jiménez et al. 2012). Some three- to four-ring parent PAHs, among them FLN, had been reported to be close to phase equilibrium in the Mediterranean and Black Seas (Castro-Jiménez et al. 2012).

Penta- and hexachlorinated PCBs are found with volatilisational trends at site $2 \mathrm{c}$, Michaniona in the Thermaikos Gulf, and all seven indicator PCBs, except PCB118, at site $1 \mathrm{~b}$, Selles Beach on Crete. They seem to be close to phase equilibrium at site $2 \mathrm{~d}$ in the Thermaikos Gulf. PCB were concluded to be net volatilisational in the eastern Mediterranean based on measurements in air in 2001-2002 and in seawater in the 1990s (18 congeners; Mandalakis et al. 2005) but close to phase equilibrium in the Aegean Sea in 2006-2007 (41 congeners; Berrojalbiz et al. 2014). HCB and $\mathrm{PeCB}$ are found net volatilisational at all three sites. HCB had been observed but close to phase equilibrium in the Aegean Sea in 2006-2007 (Berrojalbiz et al. 2014). The direction of air-water gas exchange of $\mathrm{HCH}$ isomers is found depositional in the Thermaikos Gulf (Fig. 4). This is, to our knowledge, the first observation of pentachlorobenzene fugacities in European marine environments.

Among the PBDEs only BDE28 seems to approach phase equilibrium $\left(f_{\mathrm{a}} / f_{\mathrm{w}}=1-20\right.$ at the three sites; Fig. 4$)$ while the other congeners tested, BDE47, BDE66, BDE100 and BDE99, were found to be depositional with $f_{\mathrm{a}} / f_{\mathrm{w}}$ in the range $10^{2}-10^{4}$ (BDE66 and BDE100 at all sites, BDE47 at site $1 \mathrm{~b}$ on Crete) or even higher (BDE99 at all sites, BDE47 at the Thermaikos Gulf sites), i.e. very far from phase equilibrium (not included in Fig. 4). 
Fig. 4 Fugacity ratios, $f_{\mathrm{a}} / f_{\mathrm{w}}$, at sites on Crete (1b Selles Beach) and in the Thermaikos Gulf $(2 \mathrm{c}$ Michaniona, 2d Loudias River estuaries). Only substances with $C_{\mathrm{w}}>$ LOQ considered. $C_{\mathrm{a}}<\mathrm{LOQ}$ reflected as bars. Gas-phase concentrations derived from particulate matter fraction determined by AAS at site 1a (see Table S3)

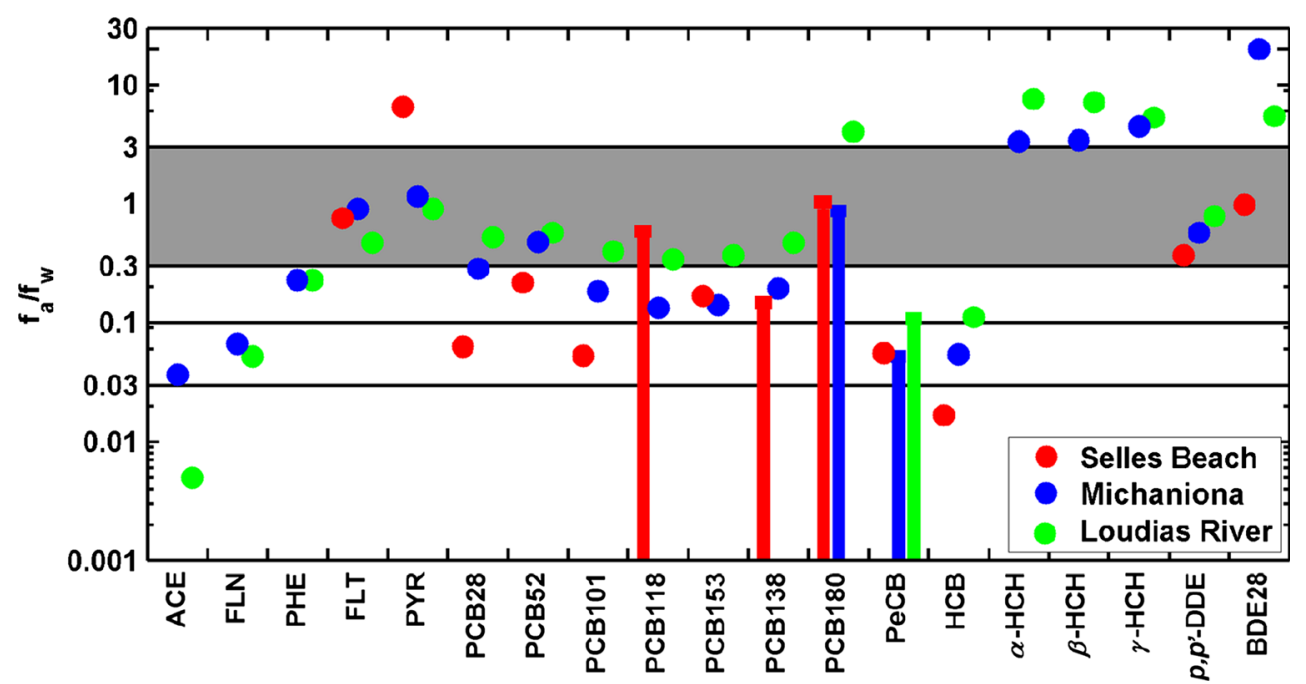

For some substances that are quickly equilibrated (within a few days) in SR, i.e. $\mathrm{HCH}$ and three-ring PAHs, the fugacities derived at the remote site $1 \mathrm{~b}$ could not be related because, at this site, the SR sample was collected 10 days after PAS sample collection. Assuming stable $C_{\mathrm{w}} \mathrm{s}$ (during these 10 days), values of $f_{\mathrm{a}} / f_{\mathrm{w}}$ for ACE, FLN and PHE and HCHs at site $1 \mathrm{~b}$ were indicated to be similar to those at the Thermaikos Gulf sites. $p, p^{\prime}-\mathrm{DDE}$ was found close to phase equilibrium.

\section{Conclusions}

The regional marine environment exposure to PTS was characterised by the determination of the concentrations of 26 substances in near-ground air and 55 substances in surface seawater. The set of substances addressed in air was reduced as a consequence of calibration of the effective PAS sampling volume $V$ based on side-by-side AAS and PAS at one of the sites ("Air" and "S2"). The comparison of the substance patterns suggests that $V$ values may not be representative across sites when PAHs significantly partitioning to the particulate phase are included (FLT and PYR in this study). This is related to the processes determining gas-particle partitioning of semivolatiles, which are dependent on particulate phase chemical properties. This is not likely relevant for PBDEs, for which phase partitioning is expectedly less influenced by particulate phase components.

Distribution of HCB, HCHs and DDX in air is found to be distributed fairly consistent. The urban to remote gradient of PCBs is only about a factor of 2. PAHs and PCBs are observed to be close to equilibrium or net volatilisational, as previously observed or suggested in the region (Mandalakis et al. 2005; Castro-Jiménez et al. 2012). HCB and PeCB are found net volatilisational for the first time. No tendency is found that $f_{\mathrm{a}} / f_{\mathrm{w}}$ would be higher at the remote site. Instead, the fugacity ratios of PCBs, DDE and $\mathrm{HCB}$ are very similar to those derived for the more polluted Thermaikos Gulf sites. The data basis is too sparse to conclude on long-term trends of the ocean burdens of most pollutants addressed. However, a long-term trend of increasing PCB seawater concentrations is indicated in the southern Aegean Sea. This is notably regarding the fact that the emissions have been declining since the 1970s, and the environmental burden in the region is expected to decline since the 1980s to 1990s (Lammel and Stemmler 2012). It could be explained by decreasing trends in other environmental compartments in the region (air, sediments) or advection (sea currents). More data, also from other seasons, are needed to consolidate such a finding.

Acknowledgments We thank Giorgos Kouvarakis and Nikolas Mihalopoulos, University of Crete, for on-site support. This research was supported by the Granting Agency of the Czech Republic (\#312334), the Czech Ministry of Education (LO1214 and LM2011028), by the European Social Fund (CZ.1.07/2.3.00/30.0037) and the European Commission FP7 (\#262254 ACTRIS).

Compliance with Ethical Standards No potential conflicts of interest (financial or non-financial) exist.

\section{References}

Akyüz M, Çabuk H (2010) Gas-particle partitioning and seasonal variation of polycyclic aromatic hydrocarbons in the atmosphere of Zonguldak, Turkey. Sci Total Environ 408:5550-5558

Berrojalbiz N, Dachs J, del Vento S, Ojeda MJ, Valle MC, CastroJiménez J, Mariani G, Wollgast J, Hanke G (2011) Persistent organic pollutants in Mediterranean seawater and processes affecting their accumulation in plankton. Environ Sci Technol 45:4315-4322

Berrojalbiz N, Castro-Jiménez J, Mariani G, Wollgast J, Hanke G, Dachs J (2014) Atmospheric occurrence, transport and deposition of polychlorinated biphenyls and hexachlorobenzene in the Mediterranean and Black seas. Atmos Chem Phys 14:8947-8959

Bidleman TF, McConnell LL (1995) A review of field experiments to determine air-water gas-exchange of persistent organic pollutants. Sci Total Environ 159:101-107 
Birgül A, Taşdemir Y (2011) Seasonal atmospheric deposition variations of polychlorinated biphenyls (PCBs) and comparison of some deposition sampling techniques. Environ Sci Pollut Res 18:396-406

Birgül A, Taşdemir Y, Cindoruk SS (2011) Atmospheric wet and dry deposition of polycyclic aromatic hydrocarbons (PAHs) determined using a modified sampler. Atmos Res 101:341-353

Biterna M, Voutsa D (2005) Polychlorinated biphenyls in ambient air of NW Greece and in particulate emissions. Environ Int 31:671-677

Bohlin P, Audy O, Škridlíková L, Kukučka P, Přibylová P, Prokeš R, Vojta S, Klánová J (2014) Outdoor passive air monitoring of semivolatile organic compounds (SVOCs): a cruitical evaluation of performance and limitations of polyurethane foam (PUF) disks. Environ Sci Processes Impacts 16:433-444

Booij K, Smedes F (2010) An improved method for estimating in situ sampling rates of nonpolar passive samplers. Environ Sci Technol 44:6789-6794

Booij K, Smedes F, van Weerlee EM (2002) Spiking of performance reference compounds in low density polyethylene and silicone passive water samplers. Chemosphere 46:1157-1161

Bruhn R, Lakaschus S, McLachlan MS (2003) Air/sea gas exchange of PCBs in the southern Baltic Sea. Atmos Environ 37:3445-3454

Castro-Jiménez J, Berrojalbiz N, Wollgast J, Dachs J (2012) Polycyclic aromatic hydrocarbons (PAHs) in the Mediterranean Sea: atmospheric occurrence, deposition and decoupling with settling fluxes in the water column. Environ Pollut 166:40-47

Cetin B, Odabasi M (2008) Atmospheric concentrations and phase partitioning of polybrominated diphenyl ethers (PBDEs) in Izmir, Turkey. Chemosphere 71:1067-1078

Chen LG, Mai BX, Bi XH, Chen SJ, Wang XM, Ran Y, Luo XJ, Sheng GY, Fu JM, Zeng EY (2006) Concentration levels, compositional profiles, and gas-particle partitioning of polybrominated diphenyl ethers in the atmosphere of an urban city in South China. Environ Sci Technol 40:1190-1196

Chrysikou LP, Samara CA (2009) Seasonal variation of the size distribution of urban particulate matter and associated organic pollutants in the ambient air. Atmos Environ 43:4557-4569

Chrysikou L, Gemenetzis P, Kouras A, Manoli E, Terzi E, Samara C (2008) Distribution of persistent organic pollutants, polycyclic aromatic hydrocarbons and trace elements in soil and vegetation following a large scale landfill fire in northern Greece. Environ Int 34: 210-225

Demircioglu E, Sofuoglu A, Odabasi M (2011) Particle-phase dry deposition and air-soil gas exchange of polycyclic aromatic hydrocarbons (PAHs) in Izmir, Turkey. J Hazard Mater 186:328-335

Diamond ML, Melymuk L, Csiszar SA, Robson M (2010) Estimation of PCB stocks, emissions, and urban fate: will our Policies reduce concentrations and exposure? Environ Sci Technol 44:2777-2783

Dosis I, Kamarianos A, Athanasiadou M, Athanasiadis I, Karamanlis X (2011) Polybrominated diphenyl ethers (PBDEs) in marine sediments of Thermaikos Gulf, Greece. Int J Environ Anal Chem 91: $1151-1165$

Dvorská A, Komprdová K, Lammel G, Klánová J, Plachá H (2012) Polycyclic aromatic hydrocarbons in background air in central Europe - seasonal levels and limitations for source apportionment. Atmos Environ 46:147-154

Galarneau E, Makar PA, Zheng Q, Narayan J, Zhang J, Moran MD, Bari MA, Pathela S, Chen A, Chlumsky R (2014) PAH concentrations simulated with the AURAMS-PAH chemical transport model over Canada and the USA. Atmos Chem Phys 14:4065-4077

Gasić B, MacLeod M, Klánová J, Scheringer M, Ilić P, Lammel G, Pajović A, Breivik K, Holoubek I, Hungerbühler K (2010) Quantification of sources of PCBs to the atmosphere in urban areas: a comparison of cities in North America, Western Europe and former Yugoslavia. Environ Pollut 158:3230-3235
Halse AK, Schlabach M, Eckhardt S, Sweetman AJ, Jones KC, Breivik K (2011) Spatial variability of POPs in European background air. Atmos Chem Phys 11:1549-1564

Harner T, Bartkow M, Holoubek I, Klánová J, Wania F, Gioia R, Moeckel C, Sweetman AJ, Jones KC (2006) Passive air sampling for persistent organic pollutants: introductory remarks to the special issue. Environ Pollut 144:361-364

Iacovidou E, Mandalakis M, Stephanou EG (2009) Occurrence and diurnal variation of polychlorinated biphenyls and polybrominated diphenyl ethers in the background atmosphere of Eastern Mediterranean. Chemosphere 77:1161-1167

IKYDA (2010) Emerging pollutants as indicators of quality status in marine environments. A comparative study between Mediterranean and Baltic Sea. Programme for the promotion of the exchange and scientific cooperation between Greece and Germany (unpublished results)

Kamarianos A, Karamanlis X, Galoupi E (2002) Pollution of coastal areas of N. Greece by organochlorine pesticides and polychlorinated biphenyls (PCBs). In: Proceedings of the 1st Environmental Conference of Macedonia, 1-4 March 2002, Thessaloniki, Greece, $116-121 \mathrm{pp}$

Kaya E, Dumanoglu Y, Kara M, Altiok H, Bayram A, Elbi T, Odabasi M (2012) Spatial and temporal variation and air-soil exchange of atmospheric PAHs and PCBs in an industrial region. Atmos Pollut Res 3:435-449

Klánová J, Čupr P, Kohoutek J, Harner T (2008) Assessing the influence of meteorological parameters on the performance of polyurethane foam-based passive air samplers. Environ Sci Technol 42:550-555

Klánová J, Diamond ML, Jones KC, Lammel G, Lohmann R, Pirrone N, Scheringer $\mathrm{M}$ et al (2011) Identifying the research and infrastructure needs for the global assessment of hazardous chemicals 10 years after establishing the Stockholm Convention. Environ Sci Technol 45:7617-7619

Kouimtzis T, Samara C, Voutsa D, Balafoutis C, Muller L (2002) PCDD/ Fs and PCBs in airborne particulate matter of the greater Thessaloniki area, $\mathrm{N}$ Greece. Chemosphere 47:193-205

Lammel G (2015) Polycyclic aromatic compounds in the atmosphere-a review identifying research needs. Polycycl Aromat Compd 35. doi: 10.1080/10406638.2014.931870

Lammel G, Stemmler I (2012) Fractionation and current time trends of PCB congeners: evolvement of distributions 1950-2010 studied using a global atmosphere-ocean general circulation model. Atmos Chem Phys 12:7199-7213

Lammel G, Sehili AM, Bond TC, Feichter J, Grassl H (2009) Gas/particle partitioning and global distribution of polycyclic aromatic hydrocarbons - a modelling approach. Chemosphere 76:98-106

Lammel G, Novák J, Landlová L, Dvorská A, Klánová J, Čupr P, Kohoutek J, Reimer E, Škrdlíková L (2010) Sources and distributions of polycyclic aromatic hydrocarbons and toxicity of polluted atmosphere aerosols. In: Zereini F, Wiseman CLS (eds) Urban airborne particulate matter: origins, chemistry, fate and health impacts. Springer, Berlin, pp 39-62

Lelieveld J, Berresheim H, Borrmann S, Crutzen PJ, Dentener FJ, Fischer H, Feichter J, Flatau PJ, Heland J, Holzinger R, Korrmann R, Lawrence MG, Levin Z, Markowicz KM, Mihalopoulos N, Minikin A, Ramanathan V, de Reus M, Roelofs GJ, Scheeren HA, Sciare J, Schlager H, Schultz M, Siegmund P, Steil B, Stephanou EG, Stier P, Traub M, Warneke C, Williams J, Ziereis H (2002) Global air pollution crossroads over the Mediterranean. Science 298:794-799

Lipiatou E, Saliot A (1991) Hydrocarbon contamination of the Rhone delta and western Mediterranean. Mar Pollut Bull 22:297-304

Liss PS, Slater PG (1974) Flux of gases across air-sea interface. Nature 247:181-184

Lohmann R, Lammel G (2004) Adsorptive and absorptive contributions to the gas particle partitioning of polycyclic aromatic hydrocarbons: 
state of knowledge and recommended parameterisation for modelling. Environ Sci Technol 38:3793-3803

Lohmann R, Dapsis M, Morgan EJ, Dekany E, Luey PJ (2011) Determining air-water exchange spatial and temporal trends of freely dissolved PAHs in an urban estuary using passive polyethylene samplers. Environ Sci Technol 45:2655-2662

Lohmann R, Booij K, Smedes F, Vrana B (2012) Use of passive sampling devices for monitoring and compliance checking of POP concentrations in water. Environ Sci Pollut Res 19:1885-1895

Mandalakis M, Tsapakis M, Tsoga A, Stephanou EG (2002) Gas-particle concentrations and distribution of aliphatic hydrocarbons, PAHs, PCBs and PCDD/Fs in the atmosphere of Athens (Greece). Atmos Environ 36:4023-4035

Mandalakis M, Berresheim H, Stephanou EG (2003) Direct evidence for destruction of polychlorinated biphenyls by hydroxyl radicals in the subtropical troposphere. Environ Sci Technol 37:542-547

Mandalakis M, Apostolaki M, Stephanou EG, Stavrakakis S (2005) Mass budget and dynamics of polychlorinated biphenyls in the east Mediterranean Sea. Glob Biogeochem Cycles 19, GB3018

Mandalakis M, Besis A, Stephanou EG (2009) Particle-size distribution and gas/particle partitioning of atmospheric polybrominated diphenyl ethers in urban areas of Greece. Environ Pollut 157:1227-1233

Manoli E, Kouras A, Samara C (2011) Polycyclic aromatic hydrocarbons in the Greek atmospheric environment. 16th international symposium on environmental pollution and its impact on life in the Mediterranean region (MESAEP2011), Ioannina, Greece, 24-27 September 2011

Mulder MD, Kukučka P, Klánová J, Kuta J, Prokeš R, Lammel G (2013) Legacy POPs and polybrominated diphenylethers in the central and eastern Mediterranean-levels in ambient air and gas-particle partitioning, poster presentation, 14th EuCheMS international conference on chemistry and the environment, Barcelona, 25-28 June 2013

Mulder MD, Heil A, Kukučka P, Klánová J, Kuta J, Prokeš R, Sprovieri F, Lammel G (2014) Air-sea exchange and gas-particle partitioning of polycyclic aromatic hydrocarbons in the Mediterranean. Atmos Chem Phys 14:8905-8915

Ozcan S, Aydin ME (2009) Polycyclic aromatic hydrocarbons, polychlorinated biphenyls and organochlorine pesticides in urban air of Konya, Turkey. Atmos Res 93:715-722

Pacyna JM, Breivik K, Münch J, Fudala J (2003) European atmospheric emissions of selected persistent organic pollutants, 1970-1995. Atmos Environ 37:S119-S131

Pozo K, Harner T, Lee SC, Wania F, Muir DCG, Jones KC (2009) Seasonally resolved concentrations of persistent organic pollutants in the global atmosphere from the first year of the GAPS study. Environ Sci Technol 43:796-803

Rusina TP, Smedes F, Klánová J, Booij K, Holoubek I (2007) Polymer selection for passive sampling: a comparison of critical properties. Chemosphere 68:1344-1351

Rusina T, Smedes F, Kobližková M, Klánová J (2010) Calibration of silicone rubber passive samplers: experimental and modeled relations between sampling rate and compound properties. Environ Sci Technol 44:362-367

Schulz-Bull DE, Petrick G, Johannsen H, Duinker JC (1997) Chlorinated biphenyls and $\mathrm{p}, \mathrm{p}^{\prime}$-DDE in Mediterranean surface waters. Croat Chem Acta 70:309-321

Schwarzenbach RP, Gschwend PM, Imboden DM (2003) Environmental organic chemistry, 2nd edn. Wiley, Hoboken

Semeena VS, Feichter J, Lammel G (2006) Significance of regional climate and substance properties on the fate and atmospheric longrange transport of persistent organic pollutants - examples of DDT and $\gamma$-HCH. Atmos Chem Phys 6:1231-1248

Shoeib M, Harner T (2002) Characterization and comparison of three passive air samplers for persistent organic pollutants. Environ Sci Technol 36:4142-4151
Smedes F (2007) Monitoring of chlorinated biphenyls and polycyclic aromatic hydrocarbons by passive sampling in concert with deployed mussels. In: Greenwood R, Mills G, Vrana B (eds) Passive sampling techniques in environmental monitoring, vol 48, Comprehensive analytical chemistry. Elsevier, Amsterdam, pp 407-448

Sofuoglu A, Cetin E, Bozacioglu SS, Sener GD, Odabasi M (2004) Shortterm variation in ambient concentrations and gas/particle partitioning of organochlorine pesticides in Izmir, Turkey. Atmos Environ 38:4483-4493

Stafilov T, Škrbić B, Klánová J, Čupr P, Holoubek I, Kočov M, ĐurišićMladenović N (2011) Chemometric assessment of the semivolatile organic contaminants content in the atmosphere of the selected sites in the Republic of Macedonia. J Chemometr 25:262-274

Stemmler I, Lammel G (2009) Cycling of DDT in the global oceans 1950-2002: world ocean returns the pollutant. Geophys Res Lett 36, L24602

Stohl A, Hitzenberger M, Wotawa G (1998) Validation of the Lagrangian particle dispersion model FLEXPART against large scale tracer experiments. Atmos Environ 32:4245-4264

Su YS, Hung H, Brice KA, Su K, Alexandrou N, Blanchard P, Chan E, Sverko E, Fellin P (2009) Air concentrations of polybrominated diphenyl ethers (PBDEs) in 2002-2004 at a rural site in the Great Lakes. Atmos Environ 43:6230-6237

Tașdemir Y, Esen F (2007) Urban air PAHs: concentrations, temporal changes and gas/particle partitioning at a traffic site in Turkey. Atmos Res 84:1-12

Terzi E, Samara C (2004) Gas-particle partitioning of polycyclic aromatic hydrocarbons in urban, adjacent coastal, and continental background sites of western Greece. Environ Sci Technol 8:4973-4978

Terzopoulou E, Voutsa D (2011) Persistent organic pollutants in marine sediments of Mediterranean and Baltic Sea. 16th international symposium on environmental pollution and its impact on life in the Mediterranean region (MESAEP2011), Ioannina, Greece, 24-27 September 2011

Tsapakis M, Apostolaki M, Eisenreich S, Stephanou EG (2006) Atmospheric deposition and marine sediment fluxes of polycyclic aromatic hydrocarbons in the east Mediterranean Basin. Environ Sci Technol 40:4922-4927

UNECE (2010) United Nations Economic Commission for Europe: hemispheric transport of air pollution 2010 - part C: persistent organic pollutants. In: Dutchak S, Zuber A (eds) Air pollution studies no. 19. New York and Geneva, $194+62 \mathrm{pp}$

UNEP (2002) United Nations Environment Programme: regionally based assessment of persistent toxic substances-Mediterranean regional report, UNEP Chemicals, Châtelaine, Switzerland, 161 pp

UNEP (2003) United Nations Environment Programme: regionally based assessment of persistent toxic substances - global report, UNEP Chemicals, Châtelaine, Switzerland, 207 pp

UNEP (2014) Stockholm Convention, United Nations Environment Programme. http://chm.pops.int/. Accessed 24 July 2014

Vasilakos C, Levi N, Maggos T, Hatzianestis J, Michopoulos J, Helmis C (2007) Gas-particle concentration and characterization of sources of PAHs in the atmosphere of a suburban area in Athens, Greece. J Hazard Mater 140:45-51

WHO (2003) Health risks of persistent organic pollutants from longrange transboundary air pollution. World Health Organization Regional Office for Europe, Copenhagen, $252 \mathrm{pp}$

Yolsal D, Salihoglu G, Tasdemir Y (2014) Air-soil exchange of PCBs: levels and temporal variations at two sites in Turkey. Environ Sci Pollut Res 21:3920-3935

Zhong G, Xie Z, Möller A, Halsall C, Caba A, Sturm R, Tang J, Zhang G, Ebinghaus R (2012) Currently used pesticides, hexachlorobenzene and hexachlorocyclohexanes in the air and seawater of the German Bight (North Sea). Environ Chem 9:405-414 